\title{
Sentinel areas: a monitoring strategy in public health
}

\author{
Áreas sentinelas: uma estratégia \\ de monitoramento em saúde pública
}

Maria da Glória Teixeira ${ }^{1}$

Maurício L. Barreto ${ }^{2}$

Maria da Conceição Nascimento Costa 3

Agostino Strina 4

David Martins Jr. 5

Matildes Prado 6

\footnotetext{
1 Instituto de Saúde Coletiva, Universidade Federal da Bahia. Rua Padre Feijó 29, Salvador, $B A$ 40110-170, Brasil. magloria@ufba.br
}

\begin{abstract}
Available techniques for monitoring the health situation have proven insufficient, thus leading to a discussion of the need for their improvement based on new data collection strategies allowing for data use by local health systems. This article presents the methodological basis for a strategy to monitor health problems utilizing demarcated intra-urban spaces called "sentinel areas" to collect fundamental social, economic, behavioral, and biological data for public health that allow for a closer approach to the reality of complex social spaces. The authors present an experience that is being developed in Salvador, Bahia, Brazil, to evaluate the epidemiological impact of an environmental sanitation program. They discuss selection criteria for the areas and the potential uses of this strategy allowing for the rapid utilization of epidemiological resources by health services and the timely application of the results to reorient and enhance health intervention practices.
\end{abstract}

Key words Monitoring; Sanitation Policy; Sanitation; Surveillance

Resumo As técnicas disponíveis para monitoramento da situação de saúde têm se mostrado insuficientes, razão pela qual discute-se a necessidade de aperfeiçoá-las com base no desenvolvimento de novas estratégias de coleta de informações, de modo a permitir seu uso pelos sistemas locais de saúde. Este artigo apresenta as bases metodológicas de uma estratégia de monitoramento de problemas de saúde que emprega espaços intra-urbanos delimitados - "áreas sentinelas" - para coleta de informações sociais, econômicas, comportamentais e biológicas que são fundamentais para a Saúde Pública por permitirem uma maior aproximação com a realidade de espaços sociais complexos. Os autores apresentam uma experiência que está sendo desenvolvida em Salvador, Bahia, Brasil, para avaliação de impacto epidemiológico resultante da implantação de um programa de saneamento ambiental. Discutem os critérios de seleção das áreas $e$ as potencialidades de uso desta estratégia, por possibilitar o emprego dos recursos epidemiológicos pelos serviços de saúde de forma ágil, e a aplicação oportuna de seus resultados na reorientação e aprimoramento das práticas de intervenção em saúde.

Palavras-chave Monitoramento; Política de Saneamento; Saneamento; Vigilância 


\section{Introduction}

Discussion of the need for new health care models to develop the Unified Health System (SUS) in Brazil have highlighted the importance of linking promotion, prevention, recovery, and rehabilitation activities at the individual and collective levels (Teixeira et al., 1998a) in the provision of integral health care. From this perspective, it is crucial to establish a mechanism to generate data and information capable of orienting the necessary actions. Enhancement and/or development of alternative forms of data collection that meet local health systems' needs has been a key proposal on the health sector's agenda (Frerichs, 1991; Teixeira et al., 1998b; WHO, 1997; Ximenes et al., 1999).

Although epidemiological surveillance includes a range of activities that contribute to integral health care, its functions and operational techniques have a limited scope which must be overcome; it is thus indispensable to have methods that are operational at the system's local levels to allow for a more complete assessment of the populations' living and health conditions. The goal is to draft and implement health care models focused on improving quality of care and consequently solving health problems of population groups without limiting the interventions merely to the diseases on the mandatory notification list.

In Brazil currently, the spread of computational tools and the availability of national databases (Moraes, 1994) via CD-ROM and the Internet have partially facilitated more systematic data use at the local level, but the component sub-systems in the Health Information System (SIS) both here in Brazil and in many other Latin American countries are still highly compartmentalized and mutually incompatible, thus hindering their use, especially by health services staff. These sub-systems have generally adopted a centralizing, vertical configuration, so that breaking down data from these databases is complex or often even impossible. Existing information allowing to capture the social, economic, and cultural contexts in the spaces where events occur are from systems outside the health sector, thus hindering or delaying access to them.

The potential use of questionnaires and the simplification of many biological tests make it possible to collect, process, and analyze risk factors and biological markers for a wide range of health problems. Such approaches have generally been limited to the field of epidemiological research, but they could be extended to routine use in monitoring health problems, fa- cilitating the incorporation of technical and scientific principles into the health services network's range of activity.

This article presents the methodological basis for a strategy to monitor health problems using demarcated intra-urban spaces referred to as "sentinel areas". The potential uses of this strategy are discussed in supplementing the existing information systems in order to enhance situational analyses and plan and evaluate the impact of health actions, particularly at the local level in large urban areas.

\section{Monitoring health: sentinel areas}

The term "monitoring" is used in various fields of knowledge with diverse meanings, such as following-up and evaluating, controlling through follow-up, observing attentively, and observing or controlling with a special purpose (Waldman, 1998). This article assumes one of the definitions of monitoring in the specific field of public health, as presented by Last (1988:107): "elaboration and analysis of routine measurements aimed at detecting changes in the community's environment or state of health". Following this line of reasoning, the fundamental principles and procedures are described for instituting a data collection system to monitor certain health problems typical of large cities, with a view towards supporting the assessment and analysis of the health situation from the perspective of implementing a new health care model referred to as Health Surveillance (Teixeira et al., 1998b).

A classical monitoring technique in public health is epidemiological surveillance, developed with the objective of systematically following and analyzing a defined set of diseases, with the purpose of orienting the interventions needed for their control, elimination, or eradication. The system is initially conditioned by the knowledge of universal notification of diseases under surveillance, obtained by means of continuous collection of data linked to the implementation and evaluation of prevention and control programs in public health.

Within epidemiological surveillance, knowledge of all suspected or confirmed cases of a disease or injury is fundamentally important, principally for diseases having intervention tools capable of interrupting their respective agents' transmission chains. However, it is acknowledged that many health problems in populations do not require knowledge of all existing cases in order to plan and implement effective collective interventions, and they therefore 
require the organization of other, more operationally agile forms of data collection and monitoring.

The term "sentinel", when used in public health, is accompanied by various qualifiers such as health units, events, or populations, whose common axis is the gathering of information with the necessary sensitivity to monitor a certain universe of phenomena (Samaja, 1996). The term was employed for the first time by epidemiological surveillance when Rutstein et al. (1976) called attention to the need to identify "sentinel events" in health, defining them as a preventable disease or incapacity or an avoidable death. Based on this principle, various countries began to include this practice in their surveillance systems, and it was expanded to include not only single events but also rare localized events and changes in logical patterns of occurrence (Aldrich \& Leaverton, 1993).

In keeping with this connotation, epidemiological surveillance systems have been using hospitals specializing in communicable diseases as "sentinel health units" which act as an alert mechanism for the investigation and adoption of control measures for serious diseases requiring hospital care.

During the last two decades, special new data collection approaches for communicable and non-communicable diseases and behavioral patterns have been developed in various countries, organized in different ways according to the problems monitored (Green et al., 1984; Van Casteren \& Leurquin, 1991). Among such approaches are systems that collect data through key informants, specialists, or general practitioners who form sentinel professional networks. A recent evaluation of some of these data collection networks showed the validity of the information generated by this method and even indicated the possibility of extending their use to analytical epidemiological studies, in addition to the descriptive ones to which they had already been applied (Schlaud \& Schawartz, 1998).

The environmental health field also seized on the strategy of identifying sentinel events such as congenital malformations, specific types of cancer, and unusual allergies, aimed at investigating the association with environmental risks and conducting relevant interventions (Aldrich \& Leaverton, 1993).

In Latin America, local experiences have been developed in this strategy for monitoring health problems by selecting and demarcating intra-urban spaces referred to as "sentinel areas" that are mutually differentiated in such a way as to represent the characteristics of a given situation or problem or even the identification of social needs particularly related to health (Samaja, 1996; UNICEF, 1992).

\section{Monitoring "sentinel areas": the experience in Salvador}

In the large and complex Brazilian city of Salvador in the State of Bahia, a strategy was adopted for monitoring "sentinel areas" with the objective of evaluating the impact on the population's health resulting from the implementation of an extensive environmental intervention project centered on a sewage system, expansion of the water supply system, and improvement of the solid waste collection system and known as the "Bahia Azul" or "Blue Bay" Program [a play on words with the name of the State of Bahia and the All Saints' Bay for which it was originally named, plus the universal ecological symbolism of blue, as in the blue agenda, and the positive connotation of blue in the Portuguese language] (Andrade, 1997). During this experience, whose design is presented in the following section, a wealth of incoming information was observed along with the possibilities for using these spaces to respond to some key questions raised by the city's epidemiological surveillance team.

The need to obtain systematic records on cases and duration of acute childhood diarrhea, prevalence of geohelminthiases, and the influence of these conditions on childhood growth and development in order to proceed with an evaluation of the impact of the Bahia Azul Program highlighted the importance of establishing a primary data collection system. However, the city's territorial extension and population density did not allow for the implementation of a universal system. The choice was thus made for a limited set of intra-urban "sentinel areas" to monitor key diseases and injuries, since this approach was simpler and sufficiently sensitive to evaluate the impact of an intervention on the health pattern and since its operational costs were compatible with the resources available for evaluation.

\section{Establishing "sentinel areas" in Salvador}

For an initial approach to the city's health and sanitation reality, a review was conducted of the existing official data and scientific publications on the city's social structure and econo- 
my, its territorial extension, and the resources available for the project, among others. Available secondary data were used to initially characterize and demarcate the areas.

For the selection of the "sentinel areas" within the context of evaluating the epidemiological impact of an environmental sanitation program predominantly focused on the expansion of the city's sewage system, it was felt that the variables "household sanitary conditions" and "income" at the spatial/populational aggregate level constituted a proxy for the population's living conditions. Utilizing data from the 1991 Census, the 1,765 census tracts in Salvador were classified in three levels as to the standard of household sewage disposal: (1) adequate sanitation, classified as adequate sewage disposal in $80 \%$ or more of the households in that census tract, defined as the household either being connected to the municipal sewage system or having its own septic tank; (2) intermediate sanitation, where 50 to $70 \%$ of the households in the census tract had adequate sewage disposal; and (3) inadequate sanitation, where less than $50 \%$ of the households in the tract presented adequate sewage disposal. The census tracts were also classified in three family income levels: (1) high, where more than $50 \%$ of the households had family incomes greater than five times the prevailing minimum wage; (2) intermediate, where more than $50 \%$ of the households had family incomes from one to four times the minimum wage; and (3) low, where more than $50 \%$ of the households had family incomes less than one minimum wage. The juxtaposition of these two classifications was expected to result in nine different possibilities for stratifying the census tracts, but since the high-income group did not include any census tract with intermediate or inadequate levels of sanitation, there ended up being only seven different types of census tracts based on sanitation and income: (a) high family income and adequate sanitation; (b) intermediate family income and adequate sanitation; (c) intermediate family income and intermediate sanitation; (d) intermediate family income and inadequate sanitation; (e) low family income and adequate sanitation; (f) low family income and intermediate sanitation; and (g) low family income and inadequate sanitation.

Since the census tracts varied greatly in their population size, an intermediate grouping phase was necessary. One of the important target groups for monitoring the environmental sanitation program's impact was children under three years of age, so it was decided that tracts with fewer than two hundred members in this age bracket be combined with other contiguous tracts from the same sanitation/income stratum. This process produced 1,100 aggregates consisting of one or more census tracts each and referred to as "micro-areas".

During the selection procedures for the sample of "micro-areas" to be used as "sentinel areas", the choice was made to focus on areas with extreme income and sanitation conditions in order to maximize the capacity to grasp the possible epidemiological impact as the Bahia Azul Program was implemented. For operational reasons, it was decided that 30 "sentinel areas" would be selected. In addition, the intervention units in the Bahia Azul Program are sewage basins, numbering 41 in Salvador, with interventions having been scheduled in 18 among the 38 which still lacked a sewage disposal system at baseline.

Thus, three of the sentinel areas were drawn randomly from among the "micro-areas" in the Barra sewage basin, an area with a high living standard, classified in stratum "a", which was then used as the "ideal standard" or benchmark for the environmental and health aspects to be monitored. Three sentinel areas were selected from different strata in the Armação sewage basin, an area with intermediate living conditions, classified in stratum " $b$ ", belonging to the group to be benefited by new sanitation work but where the sewage system construction had already begun at baseline. The 24 other sentinel areas were drawn randomly from the last strata in the classification ("e", "f", and "g"), located in eight of the 18 sewage basins to be benefited by the Bahia Azul Program (Calafate, Cobre, Lobato, Mangabeira, Médio Camurujipe, Paripe, Periperi, and Tripas) and belonging to the poorest census tracts in the city (Barreto et al., 1997).

\section{Discussion}

This experience has made important contributions to the health system in Salvador, including follow-up on the occurrence of diarrhea in the 0-3-year age bracket in the "sentinel areas", revealing a non-uniform distribution in the prevalence and incidence of cases in the different areas, with the lowest rates observed among children residing in the areas with the best sanitation conditions (Strina et al., 2000). Comparison of these results with those to be obtained after the environmental intervention will indicate the impact of the sanitation construction work (Barreto et al., 1997; Strina et al., 1998). Studies are also being conducted on the preva- 
lence of intestinal parasites and reinfection rates in groups of schoolchildren (Prado et al., 2001); the environmental sanitation situation; seroprevalence and incidence of dengue virus infection (Teixeira et al., 1999); risk factors for seronegativity for IgG antibodies against measles (Andrade et al., 1999); and perception of the environmental situation, from an anthropological approach (Killinger et al., 2000), among others. Based on the social and environmental characteristics of the "sentinel areas" and using multivariate classificatory techniques (principal components and cluster analysis), these 30 "sentinel areas" were grouped into four strata showing a strong correlation between environmental and social conditions and the level of health of their resident populations (Milroy et al., 2001).

Preliminary results from some of these studies already point to the strategy's great potential and timeliness, supporting the city's epidemiological surveillance with previously unknown information, enhancing the analyses of the health situation and fostering the development of special epidemiological studies designed by the research team.

In an analogy with the choice of strategic points for monitoring environmental pollution, the sentinel areas constitute hierarchical observation points represented by populational spaces where one monitors specific markers of health, economic, and social problems with the potential to generate knowledge contributing to an understanding of the epidemiological structure of the populations under surveillance in each context (Samaja, 1996). This dynamic feeds the assessment of health problems and the resulting definition of specific intervention processes for each situation.

Information generated by this strategy can be generalized or extrapolated to the extent that one incorporates into the "sentinel areas" concept the notion of "qualitative representativeness", where inference is made possible not by utilizing formal arguments based on probabilities estimated from the properties of the statistical distributions obtained from a large number of samples, as occurs with "statistical representativeness", but by substantive arguments, since one considers preexisting knowledge on the specific universe and the spatial/ populational units studied to form a judgment on the observed differences and similarities. The pertinence of this argument lies in the fact that this strategy does not aim at quantitative knowledge, but at the detection of indications of changes in the normal patterns or in the occurrence of new health problems. Changes in the epidemiological patterns should serve as "alert calls" to motivate and orient the intervention, detect impact, or even indicate the need to conduct special studies (Samaja, 1996).

Such a strategy was deployed in 1986 by UNICEF in Guatemala and subsequently in Nicaragua and Honduras to study trends in infant mortality, vaccine coverage, knowledge and use of oral rehydration therapy, schooling/literacy, and others, the results of which have become a complementary source and multiplying element in the routine information system (UNICEF, 1992).

\section{Final comments}

The essence of this strategy lies in the possibility of a closer approach to the concrete reality of interactive phenomena permeating the health/disease process by prioritizing "space" as a study category, incorporating the historical and social nature of the way the space was occupied as an inherent component in the determinants of living conditions. "Space" becomes particularly important in large metropolises, which contain elements of diverse origins and ages with a multiplicity of capital, work, and cultural relations (Santos, 1992).

Inherent to "sentinel areas" are two fundamental characteristics displaying the potential of this methodology as a complementary strategy for overcoming certain constraints and deficiencies in health information systems. The first relates to the methodology's conceptualization, allowing for the identification of health problems on a time scale closer to the occurrence of the events; it allows for surveys and analyses of information in different social contexts represented by the diverse typologies of the respective "sentinel areas"; it contributes to the study of processes and conditions that are beyond the reach of traditional strategies; and it makes possible the incorporation of other elements (perception, behaviors, and attitudes) in the analyses and interventions. The second characteristic relates to its operability and costs, which can be absorbed by the local levels of the health system since it utilizes the preexisting infrastructure of human resources and materials and is limited to a small universe located within their territorial range.

The in-depth study of demarcated areas can allow for analytical procedures for a large number of variables that are important for orienting intervention processes in the field of public health, because for each "needs profile" there is a corresponding "problems profile"; in 
addition, the latter can be expressed differently in distinct social spaces, seen as an expression of the population's living conditions (Costa \& Teixeira, 1999).

Because this strategy offers other elements in timely fashion that are not captured by the traditional information system, besides the possibility of tapping the potential of epidemiological resources, it allows for the development of simpler studies while maintaining scientific rigor and rapid incorporation of innovations, technologies, and information generated by the technoscientific production system, meanwhile informing on factors pertaining to exposure, frequency, and spatial distribution of health/disease phenomena, making it possible to trace a picture that is closer to reality.
Outstanding potential applications of this strategy include follow-up on high-profile events that may or may not belong to the list of diseases under surveillance; timely data surveys of individual and collective health; specific surveys ranging from information on the perception of health problems to prevalence estimates for specific biological markers; data surveys on the environmental and socioeconomic context of populations; and principally contributions to analyses of living and health conditions. The "sentinel areas" strategy is thus seen as contributing to the reorientation and enhancement of health intervention practices.

\section{References}

ALDRICH, T. \& LEAVERTON, P. E., 1993. Sentinel event strategies in environmental health. Annual Review of Public Health, 14:205-217.

ANDRADE, A. M. S.; TEIXEIRA, M. G.; CARDOSO, F. A. \& CARNEIRO, G., 1999. Diagnóstico da situação de imunidade para o sarampo em população residente em diferentes áreas da cidade de Salvador/ Bahia. Revista da Sociedade Brasileira de Medicina Tropical, 32(Sup. 1):175.

ANDRADE, M. R., 1997. O saneamento na Bahia: Situação atual e perspectivas. Análise e Dados, 7:5-12.

BARRETO, M.; STRINA, A.; PRADO, M.; COSTA, M. C.; TEIXEIRA, M. G.; MARTINS Jr., D.; PEREIRA, J. J. \& OLIVEIRA, A., 1997. Saneamento básico: Impacto epidemiológico do Programa Bahia Azul. Análise e Dados, 7:24-38.

COSTA, M. C. N. \& TEIXEIRA, M. G. L. C., 1999. A concepção de "espaço" na investigação epidemiológica. Cadernos de Saúde Pública, 15:271-279.

FRERICHS, R. R., 1991. Epidemiologic surveillance in developing countries. Annual Review of Public Health, 12:257-280.

GREEN, L. A.; WOOD, M.; BECKER, L.; FARLEY Jr., E. S.; FREEMAN, W. L.; FROOM, J.; HAMES, C.; NIEBAUER, L. J.; ROSER, W. W. \& SEIFERT, M., 1984. The ambulatory sentinel practice network: Purposes, methods, and policies. Journal of Family Practice, 18:275-280. 
KILLINGER, C. L.; GOES, J. C.; MENEZES, E. A; GIL, A. O. F. \& SOUZA, E. C. F., 2000. Etnografia do saneamento, limpeza e saúde: Um estudo de caso nas unidades domésticas. Ciência \& Saúde Coletiva, 5(Sup.):83.

LAST, J. M., 1988. A Dictionary of Epidemiology. New York: Oxford University Press.

MORAES, I. H. S., 1994. Informações em Saúde: Da Prática Fragmentada ao Exercício da Cidadania. Rio de Janeiro: Editora Hucitec/ABRASCO.

PRADO, M. S.; BARRETO, M. L.; STRINA, A.; FARIA, J. A. S.; NOBRE, A. A. \& JESUS, S. R., 2001. Prevalência e intensidade da infecção por parasitas intestinais em crianças na idade escolar na cidade de Salvador. Revista da Sociedade Brasileira de Medicina Tropical, 34:99-101.

RUTSTEIN, D. D.; BERENBERG, W.; SCHALMERS, T. C.; CHILD, C. G.; FISCHMAN, A. P. \& PERRIN, E. D., 1976. Measuring the quality of medical care: A clinical method. New England Journal of Medicine, 294:582-588.

SAMAJA, J., 1996. Muestras y representatividad en vigilancia epidemiológica mediante sitios centinelas. Cadernos de Saúde Pública, 12:309-319.

SANTOS, M., 1992. Espaço e Método. São Paulo: Nobel.

SCHLAUD, M. \& SCHAWARTZ, F. W., 1998. Sentinel practice networks - Opportunities and limitations. Journal of Epidemiology and Community Health, 52(Sup. 1):1S.

STRINA, A.; ASSIS, A. M. O.; GOES, J. C. L.; SANTOS, C. A.; LARREA, K. C.; MARTINS Jr., D.; FALCÃO, A. C.; MARTINS, M.; PRADO, M. \& BARRETO, M. L., 1998. Diarréia, estado nutricional nas crianças e saneamento: Delineamentos metodológicos. In: 4o Congresso Brasileiro de Epidemiologia, Resumos, pp. 426-427, Rio de Janeiro: ABRASCO.

STRINA, A.; BARRETO, M. L.; SOUZA, C. A. T. \& PRADO, M. S., 2000. Saneamento ambiental e desigualdades na ocorrência da diarréia em crianças. In: I Seminário Nacional Saúde e Ambiente no Processo de Desenvolvimento, Resumos, p. 251, Rio de Janeiro: Fundação Oswaldo Cruz, Ministério da Saúde.
TEIXEIRA, C. F; PAIM, J. S. \& VILASBÔAS, A. L., 1998a. SUS (Sistema Único de Saúde), modelos assistenciais e vigilância da saúde. Informe Epidemiológico do SUS, 7:7-28.

TEIXEIRA, M. G.; BARRETO, M. L.; TRAVASSOS-DAROSA, A.; VASCONCELOS, P. \& BARRETO, M. L. 1999. Diferenças intraurbanas na circulação dos vírus do dengue em uma grande cidade - Salvador-Bahia. Revista da Sociedade Brasileira de Medicina Tropical, 32(Sup. 1):174.

TEIXEIRA, M. G.; PENNA, G. O.; RISI, J. B.; PENNA, M. L.; ALVIM, M. F; MORAES, J. C. \& LUNA, E., 1998b Seleção das doenças de notificação compulsória: Critérios e recomendações para as três esferas de governo. Informe Epidemiológico do SUS, 7:7-28.

UNICEF (Fondo de las Naciones Unidas para la Infancia), 1992. El Monitoreo de las Metas en el Contexto de los PNAs y Sitios Centinela. Ciudad de Guatemala: UNICEF. (mimeo.)

VAN CASTEREN, V. \& LEURQUIN, P., 1991. Eurosentinel: Concerted Action on Sentinel Health Information System with General Practitioners. Final Report. Brussels: Institute of Hygiene and Epidemiology.

WALDMAN, E., 1998. Usos da vigilância e da monitorização em Saúde Pública. Informe Epidemiológico do SUS, 7:7-26.

WHO (World Health Organization), 1997. World Health Day 1997: Emerging Infectious Diseases. Geneva: WHO.

XIMENES, R. A. A.; MARTELLI, C. M. T.; SOUZA, W. V. I.; LAPA, T. M.; ALBUQUERQUE, M. F. M.; ANDRADE, A. L. S. S.; MORAIS NETO, O. L.; SILVA, S. A.; LIMA, M. L. C. \& PORTUGAL, J. L., 1999. Vigilância de doenças endêmicas em áreas urbanas: A interface entre mapas de setores censitários e indicadores de morbidade. Cadernos de Saúde Pública, 15:53-61.

Submitted on 19 September 2000

Final version resubmitted on 19 October 2001

Approved on 12 December 2001 